The lability of plasma growth hormone levels in normal subjects makes it difficult to interpret variations seen in acute medical illnesses. The figures reported here show that the concentration is increased in patients with severe diabetic ketosis and that it falls as the blood sugar falls in response to treatment. This is in keeping with the report by Unger (1965). The opposite trend seen in patients with hyperosmolar nonketotic diabetic coma suggests that in the latter, where some circulating insulin persists, glucose is entering the cells in that part of the nervous system where the stimulus to growth hormone release is inversely related to intracellular glucose availability. There is one report of an increase of growth hormone levels in sandfly fever (Beisel et al., 1968). The high values shown in Table III do not provide any meaningful pattern. The two patients with the highest levels $(190$ and $320 \mathrm{~m} \mu \mathrm{g} . / \mathrm{ml}$.) died and on necropsy no evidence of a pituitary adenoma was found.

The studies were carried out in the Institute of Clinical Research, the Middlesex Hospital Medical School, where H. S. J. has been Leverhulme Research Fellow. J.D.N.N. wishes to acknowledge support from the Clinical Research Committee of the Middlesex Hospital, the Royal College of Physicians of London-Joseph Senior White Fellowship-and the Medical Research Council. A preliminary account of some of the results was incorporated in a paper read by J.D.N.N. at the Royal Society of Medicine in October 1968 .

\section{REFERENCES}

Bailey, R. R., Abernethy, M. H., and Beaven, D. W. (1967). Lancet, 1, 970

Bassøe, H. H., Aarskog, D., Thorsen, T., and Støa, K. F. (1965). Acta Medica Scandinavica, i77, 701 .

Bayliss, R. I. S. (1955). British Medical Fournal, 1, 495.

Beiscl, W. R., Bruton, J., Anderson, K. D., and Sawyer, W. D. (1967) fournal of Clinical Endocrinology and Metabolism, 27, 61

Beisel, W. R., Woeber, K. A., Bartclloni, P. J., and Ingbar, S. H. (1968). fournal of Clinical Endocrinology and Metabolism, 28, 1220.
Connolly, C. K., and Wills, M. R. (1967). British Medical fournal, 2, 25.

Cornil, A., Copinschi, G., Leclercq, R., and Franckson, J. R. M. (1968), Acta Endocrinologica, 58, 1.

Engel, E., Helmreich, M. L., Hertoghe, J., Fabre, J., Muller, A. F., and Mach, R. S. (1955). Semaine des Hôpitaux de Paris, 31, 78.

Espiner, E. A. (1966). Fournal of Endocrinology, 35, 29.

Glenchur, H., and Doe, R. P. (1960). Clinical Research, 8, 222

Greig, W. R., Jasani, M. K., Boyle, J. A., and Maxwell, J. D. (1968). In The Investigation of Hypothalamic-Pituitary-Adrenal Function, edited by V. H. T. James and J. Landon, p. 175. London, Camedited by V. H. T. Jam

Jacobs, H. S. (1969). Fournal of Clinical Pathology. In press.

Kass, E. H. (1962). Transactions of the Association of American Physi cians, $75,198$.

Kimball, H. R., Lipsett, M. B., Odell, W. D., and Wolff, S. M. (1968). Journal of Clinical Endocrinology and Metabolism, 28, 337.

Klein, A. J., and Palmer, L. A. (1963). American fournal of Cardiology, 11, 332 .

Klein, R., Papadatos, C., Fortunato, J., and Byers, C. (1955). fournal of Clinical Endocrinology and Metabolism, 15, 215

Knapp, M. S., Keane, P. M., and Wright, J. G. (1967). British Medical Fournal, 2, 27.

Lillehei, R. C., Longerbeam, J. K., Bloch, J. H., and Manax, W. G. (1964). Annals of Surgery, 160, 682.

Logan, R. W., and Murdoch, W. R. (1966). Lanct, 2, 521.

Mattingly, D.'(1962). Fournal of Clinical Pathology, 15, 374.

Mattingly, D., and Tyler, C. (1965). Proceedings of the Royal Society of Medicine, 58, 1010 .

Migeon, C. J., Kenny, F. M., Hung, W., and Voorhess, M. L. (1967). Pediatrics, 40, 163

Murray, D. (1967). Fournal of Endocrinology, 39, 571

Nabarro, J. D. N. (1967). In The Human Adrenal Cortex, edited by G. E. W. Wolstenholme and R. Portar, p. 79. London, Churchill. Perkoff, G. T., Sandberg, A. A., Nelson, D. H., and Tyler, F. H. (1954). Archives of Internal Medicine, 93,1

Preeyasombat, C., Richards, C., Silverman, M., and Kenny, F. M. (1965). American fournal of Diseases of Children, 110, 370.

Roginsky, M. S., and Duffy, J. (1967). Excerpta Medica International Congress Series, No. 140 , p. 196

Sandberg, A. A., Eik-Nes, K., Migeon, C. J., and Samuels, L. T. (1956), fournal of Clinical Endocrinology and Metabolism, 16, 1001.

Shenkin, H. A. (1964). Neurology, 14, 1112.

Shubin, H. and Weil, M. H. (1966). Fournal of the American Medical Association, 197, 808 .

Sprunt, J. G., and Browning, M. C. K. (1967). Lancet, 1, 1160.

Unger, R. H. (1965). Fournal of the American Medical Association, 191 945.

\title{
Significance of Signs and Symptoms in Benign Prostatic Hypertrophy
}

\author{
J. E. CASTRO,* M.B., B.SC., F.R.C.S.ED. ; H. J. L. GRIFFITHS, † M.B., B.S., D.M.R.D. \\ R. SHACKMAN, $\ddagger$ M.B., B.S., F.R.C.S.
}

Cummary : Measurements of intravesical pressure, $\checkmark$ urinary flow rate, retrograde cystographic residual urine, reflux of contrast medium into the prostatic ducts, and radiological prostate size were made in 45 men with benign prostatic hypertrophy. These factors were all found to be good clinical indices of the degree of urethral resistance to micturition; on the other hand, there was no relation between the latter and the severity of symptoms.

\section{Introduction}

Sometimes there are virtually no doubts about the clinical indications for prostatectomy-for example, chronic retention

- Research Fellow, Urological Unit, Department of Surgery, Royal Postgraduate Medical School, London W.12; Honorary Registrar, Hammersmith Hospital, London W.12.

+ Registrar, Department of Radiodiagnosis, Hammersmith Hospital, London W.12.

‡ Professor of Urology, Hammersmith Hospital, London W.12. with overflow incontinence or recurrent acute painful retention -but it is not always so easy to assess the significance of symptoms such as hesitancy, dribbling, and urgency in this respect. Indeed, the interpretation of such symptoms is subject to wide variation (Wildbolz, 1958). If, however, it could be easily shown that there is high urethral resistance to micturition in patients with these symptoms (Claridge and Shuttleworth, 1964 ; Holm, 1964), prostatectomy would be more rational, for the aim of such operative treatment is primarily to reduce this resistance (Scott et al., 1967). The studies reported in this paper were designed to establish whether or not any correlation exists between the clinical and radiological findings and urethral resistance.

\section{Methods}

Forty-five patients, referred by their family doctor for urological assessment, with a provisional diagnosis of prostatism and with benign enlargement of the prostate on digital rectal 
examination, were studied. None had been subjected to recent urethral instrumentation, none had taken drugs known to affect the urinary tract (Feaver et al., 1967), and none had a blood urea greater than $80 \mathrm{mg} . / 100 \mathrm{ml}$. Patients with prostatic cancer diagnosed by clinical examination, serum acid phosphatase determinations, and skeletal radiology were excluded.

In each patient the symptoms of urgency, hesitancy, dysuria, and dribbling were graded $0-3 \quad(0=$ absent, $1=$ slight, 2 =moderate, $3=$ severe) and the patient's own assessment of his urinary stream was graded 3-0. A total symptom score was thus obtained. Frequency-the total number of times a patient had to void during 24 hours-and nocturia-the total number of times a patient had to rise from bed to void-were recorded for one week and the mean values were deduced. Patients were assessed only when their urine was sterile.

The transverse diameter of the prostate was estimated by digital rectal examination, and blood was taken for blood urea estimations.

Excretion urograms, retrograde cystograms, and direct measurements of residual urine by urethral catheterization immediately after micturition and immediately before retrograde cystography were done in each case. Special attention was paid to the contrast films of the lower urinary tract, bladder trabeculation, reflux of contrast into the prostatic ducts during micturition, and the length of the prostatic urethra from the bladder base to the external urethral sphincter were noted (Vermooten and Schweinsberg, 1964). Residual urine seen on the $x$-ray films and prostatic indentation of the bladder base were measured by planimetry (Griffiths and Castro, 1969). A planimeter is an apparatus with jointed levers and a tracingpoint on an arm which is moved around the perimeter of either the residual urine shadow or the prostatic soft-tissue shadow. The area enclosed within this is given to scale by the revolutions of a small wheel which supports the arm. All measurements were corrected for magnification by fixing an opaque marker of known size to the patient and determinations of residual urine during excretion radiography and retrograde cystography were made respectively on films taken with a $35^{\circ}$ downward tilt of the $x$-ray tube and with the tube horizontal.

From simultaneous measurements of the maximal rate of urinary flow and maximal intravesical pressure (von Garrelts, 1956 ; Castro and Griffiths, 1969), the calculated effective crosssectional area of the urethra, which is inversely proportional to the degree of urethral resistance or obstruction, was derived (Rankin, 1967). In practice, two values were obtained in each case, and the average was used for the statistical analysis. When the patients were voiding they were asked to empty their bladder as completely as possible, and the total voided volumes were measured.

The clinical and radiological data were compared with the calculated effective cross-sectional area of the urethra in all 45 patients and the correlation coefficient (r) was calculated. Qualitative results were analysed by $t$ tests for unpaired data.

\section{Results}

The calculated effective cross-sectional area of the urethra was found to range from 0.004 to $0.062 \mathrm{sq} . \mathrm{cm}$. (mean 0.03 sq. cm., S.D. 0.016) in the 45 patients, and no correlation could be found between it and the symptoms in individual cases $(r=0.26$ for the symptom score, $r=0.08$ for frequency, and $r=0.03$ for nocturia). Neither was there correlation with the size of the prostate estimated by rectal examination $(r=0.26)$ and residual urine measured by catheterization $(r=0 \cdot 19)$.

${ }^{1}$ Urinary flow rates were determined by getting the patients to micturate into a cylinder which had a transducer fitted to its base. Intravesical pressures and rectal pressures were determined by transducers connected respectively to a fine urethral catheter and to a
Patients with blood urea values greater than $38 \mathrm{mg} . / 100 \mathrm{ml}$. did not differ from those with lower values $(t=0.015, \mathbf{P}=0.9)$ (Fig. 1).

Fig. 1.- To show that the calculated effective urethral area is similar in patients with a rased blood urea $(>38 \mathrm{mg} / 100 \mathrm{ml})$ ( and in those with normal values $(t=0.015, \mathrm{P}=0.9)$.

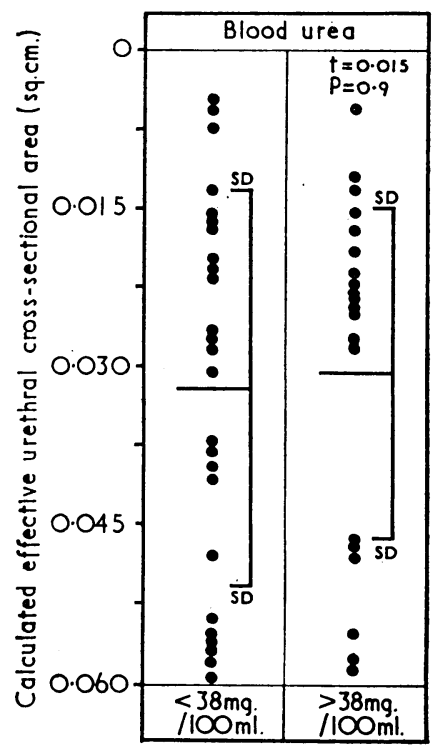

There was also no correlation to be found between the calculated effective cross-sectional area of the urethra and measurements of residual urine during intravenous pyelography $(r=0 \cdot 25)$. However, planimetric measurements of residual urine in the post-micturition retrograde cystograms correlated moderately well $(r=0.43$ ) (Fig. 2 ) but the radiological estima-

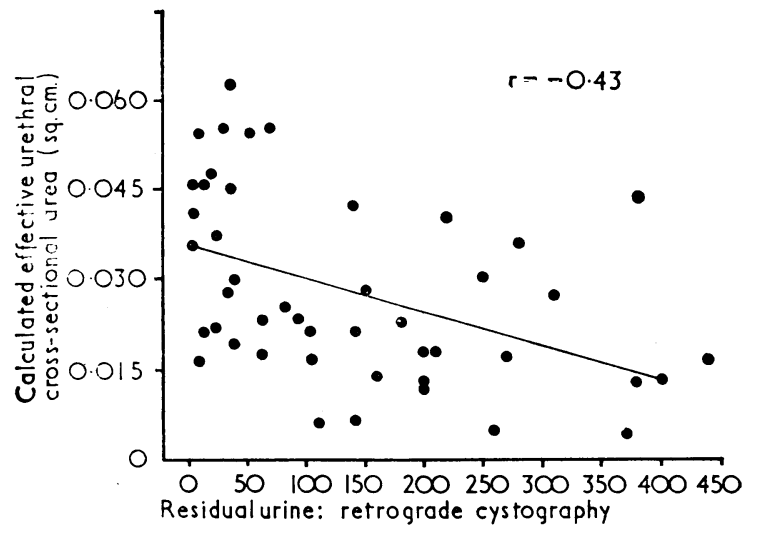

FIG. 2.-Correlation between planimetric measurements of residual urine in post-micturition retrograde cystograms and the calculated effective cross-sectional area of the urethra $(=$ the calculated effective cross-sectional area of the urethra (
$-0.43)$. The calculated effective urethral cross-sectional area $=(1 \cdot 18-0.0018 \times$ residual urine $) \div 31 \cdot 3$.

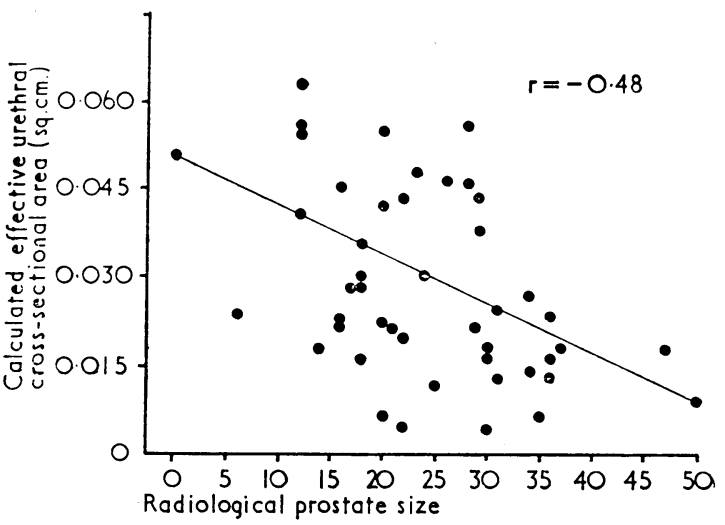

FIG. 3.-Correlation between planimetric measurements of the radiological assessment of the size of the prostate and calculradiological assessment of the size of the prostate and calculated effective cross-sectional area of the urethra $(r=-0.40)$.
The calculated effective cross-sectional area $=(1.52-0.024 \times$ prostate size) $\div 31 \cdot 3$ 
tions of the length of the prostatic urethra correlated only slightly $(r=0 \cdot 28)$. Digital measurements of prostate size did not correlate $(r=0.20)$ with the cross-sectional area of the urethra, whereas there was fairly good correlation with the radiological measurements of prostate size $(r=0.40)$ (Fig. 3). There was no significant difference in respect of the cross-sectional area of the urethra between those patients with and those without radiological evidence of bladder trabeculation $(t=1 \cdot 2, \mathrm{P}=0 \cdot 2)$ (Fig. 4), but in the cases in which there was reflux of radiological contrast into the prostatic ducts during retrograde cystography the cross-sectional area of the urethra was found to be significantly less than those without it $(t=2.57 ; \quad \mathrm{P}=0.02)$ (Fig. 5).
Figure 4

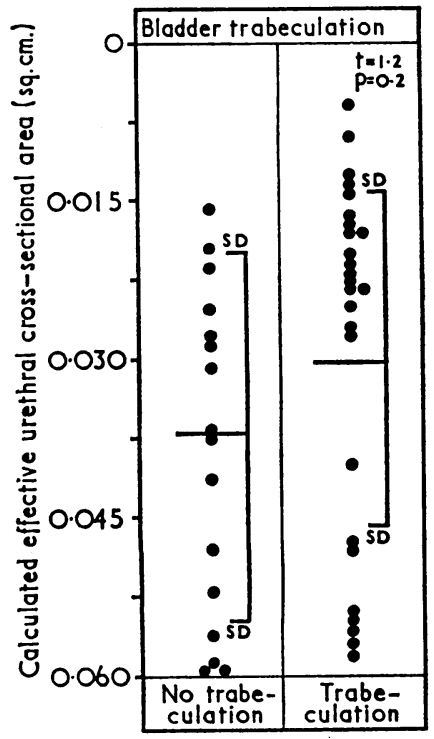

Flgure 5

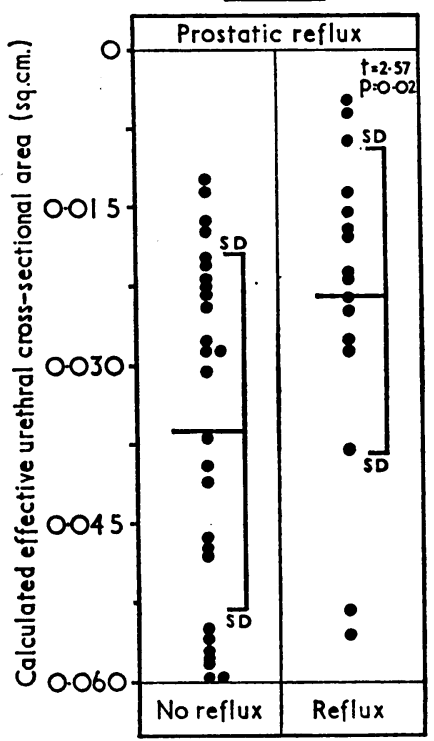

Fig. 4.-To show that calculated effective urethral area is similar in patients showing radiological bladder trabeculation and in those without it $(t=1 \cdot 2, \mathrm{P}=0 \cdot 2)$. Fig. 5. - To show that the calculated effective urethral area is significantly higher in patients showing prostatic reflux than in those without it $(t=2.57, P=0.02)$.

When the maximal rates of urinary flow and the total urine volumes were compared with the cross-sectional area of the urethra the correlations were good ( $r=0.96$ (Fig. 6) and 0.72 respectively).

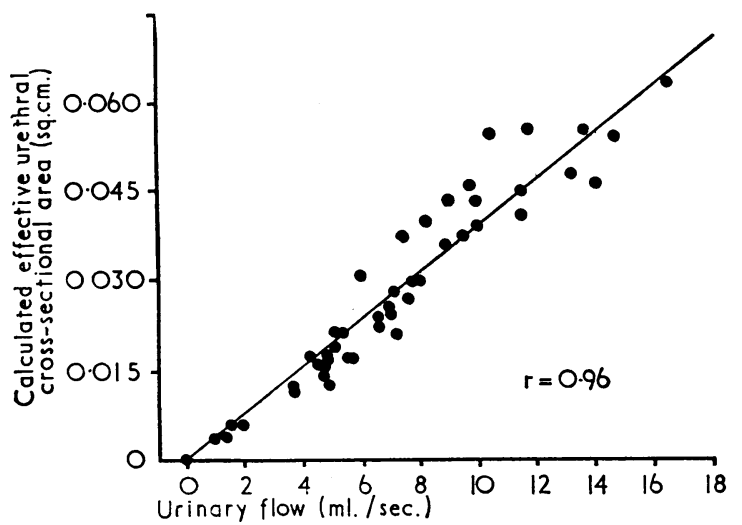

FIG. 6.-Correlation between urinary flow rates and calculated effective cross-sectional areas of the urethra $(r=0.96)$. The calculated effective cross-sectional area $=(0.13 \times$ urinary flow rate) $\div 31 \cdot 3$.

\section{Discussion}

Although there was a good correlation between voided volumes and urethral resistance, we used a standard volume, not exceeding $400 \mathrm{ml}$., to fill the bladders, so that conclusions drawn from this particular comparison may not be valid. How- ever, our studies have shown that varying degrees of urethral resistance can be assessed in individual prostatic patients by determining the maximal rate of urinary flow, by planimetric measurement of the prostatic indentation of the bladder base and residual urine in retrograde cystograms, by the radiographic length of the prostatic urethra, and by reflux of contrast into the prostatic ducts. All these measurements are objective, are easy to obtain, and require no elaborate equipment.

The maximal urinary flow rate gives the best correlation with urethral resistance ; moreover, its use avoids any need for urethral catheterization and it is applicable to routine and repeated assessment of patients (Drake, 1948 ; Smith, 1965; Smith et al., 1966). Provided voided urine volumes are not less than $150 \mathrm{ml}$. it is the best objective index for advising prostatectomy (Kaufmann, 1957).

The view that "a catheter is the most important instrument for examination of a patient with prostatism" (Flocks, 1963) may be ill-founded ; for when urethral resistance was compared with residual urine volumes determined by urethral catheterization no correlation could be found. Neither was any correlation found between the planimetered measurements of residual urine on the post-micturition bladder films of the intravenous pyelography series (von Garrelts, 1957; Holm, 1964) and urethral resistance. But when the planimetered determinations of residual urine are made from retrograde cystogram films the correlation is quite good. Failure to empty the "post-prostatic pouch" through a urethral catheter and premature voiding during intravenous pyelography before the bladder has had time to fill could respectively explain these observations: at least two hours are required to fill a bladder when the kidneys are secreting urine at a rate of $2 \mathrm{ml} . / \mathrm{min}$.

Digital rectal examinations of the size of the prostate did not correlate at all with the urethral resistance, but comparison between radiographic assessment of the gland and urethral resistance is significantly better and, moreover, suggested that there was a direct relation between size and the degree of obstruction. It has been claimed that the radiographic length of the prostatic urethra may be used as an index of the size of the gland, but our studies have shown that it is of little help for predicting urethral resistance and indeed is not as valuable as planimetric measurements of the radiological prostatic impression at the bladder base.

Severe outflow tract obstruction may be present without radiological evidence of bladder trabeculation, but the presence of reflux of contrast into the prostatic ducts is significant and suggests high urethral resistance.

Because we were unable to find any good correlation between the subjective urinary symptoms and the degree of urethral resistance in individual patients, and since we know that significant subjective improvement can occur in "prostatic" patients given placebo (Damrau, 1962 ; Castro et al., 1969), it follows that symptomatic assessment alone may be significantly influenced by errors of expression and interpretation on the part of the patient and his surgeon, and it might be better, therefore, to employ an objective evaluation and to think rather in terms of urethral resistance. If this is a rational concept then measurements of the rates of urinary flow, retrograde cystographic residual urine, reflux of contrast into the prostatic ducts, and the size of the prostate measured radiologically should be part of the standard assessment of patients under consideration for prostatectomy.

We wish to thank G. D. Searle \& Co. Ltd. for support and the statistical advice of Mr. D. Edwards,

\section{REFERENCES}

Castro, J. E., and Griffiths, H. J. L. (1969). Unpublished. Castro, J. E., Griffiths, H. J. L., and Edwards, D. E. (1969). Unpublished.

published.
Claridge, M., and Shuttleworth, K. E. D. (1964). Investigative Urology, 
Damrau, F. (1962). Fournal of the American Geriatric Society, 10,

Drake, W. M. (1948). Fournal of Urology, 59, 650.

Feaver, B. D., Usher, M., and MacEwan, D. W. (1967). Fournal of the Canadian Association of Radiologists, 18, 442.

Flocks, R. H. (1963). In Urology, 2nd ed., vol. 2, edited by M. F. Campbell, p. 1158

Garrelts, B. von (1956). Acta Chirurgica Scandinavica, 112, 326

Garrelts, B. von (1957). Acta Chirurgica Scandinavica, 114, 197.

Griffiths, H. J. L., and Castro, J. E. (1969). Unpublished.

Holm, H. H. (1964). Acta Radiologica, Suppl. No. 231.

Kaufman, J. J. (1957). Fournal of Urology, 78, 97.
Rankin, J. T. (1967). British fournal of Urology, 39, 594.

Schwartz, O. (1920). Wiener Archiv für innere Medizin, 1, 455.

Scott, F. B., Cardus, D., Quesada, E. M., and Riles, T. (1967). Southern Medical fournal, 60, 948.

Smith, J. C. (1965). Lancet, 1, 90.

Smith, J. C. British Fournal of Urology, 38, 542 .

Thumann, R. C., jun. (1951). American fournal of Roentgenology, 65 , 593.

Vermooten, V., and Schweinsberg, M. (1964). Radiology, 182, 1010.

Wildbolz, E. (1958). Proceedings of the Royal Society of Medicine, 51, 1029.

\title{
Effects of a Cardio-selective Beta-adrenergic Blocker (I.C.I. 50172) at Exercise in Angina Pectoris
}

\author{
N.-H. ARESKOG, ${ }^{*}$ M.D. ; L. ADOLFSSON,* M.D.
}

\begin{abstract}
Summary : A cardio-selective beta-adrenergic blocking $\checkmark$ agent (I.C.I. 50172), which has been studied both in normal subjects and in patients with angina pectoris during and after a standardized work test, produced a significant increase in the exercise tolerance of the patients. These favourable effects are comparable with those of propranolol.
\end{abstract}

One patient with severe bronchial asthma and coronary insufficiency treated with I.C.I. 50172 improved and his respiratory function was not impaired.

\section{Introduction}

The qualitatively new beta-adrenergic blocking drug I.C.I. 50172 (Eraldin; 4-(2-hydroxy-3-isopropylaminopropoxy) acetanilide) acts predominantly on cardiac beta-receptors. Doses which block cardiac beta-receptors have no influence on the beta-receptors of the bronchial and vascular smooth muscle

\footnotetext{
* Physician, Department of Clinical Physiology, Region Hospital,
} Linkoping, Sweden.
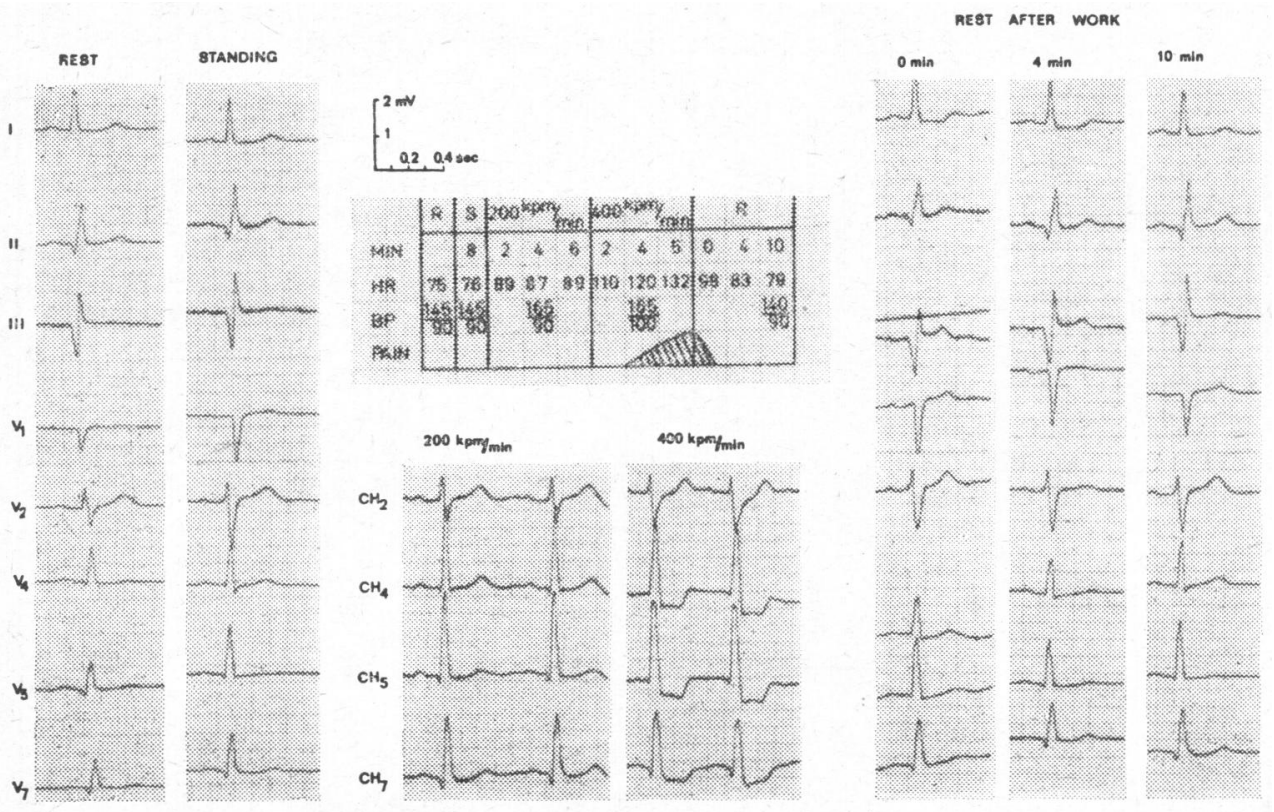

Test procedure.
(Dunlop and Shanks, 1968 ; Barrett et al., 1968 ; Gibson and Sowton, 1968 ; Macdonald and McNeill, 1968). Unlike propranolol it has intrinsic sympathomimetic activity but no local anaesthetic (quinidine-like) action (Dunlop and Shanks, 1968). It has a far longer half-life (10 hours) than propranolol (two hours) (Fitzgerald and Scales, 1968). Thus this new beta-adrenergic blocking agent is interesting from many clinical points of view. This report concerns its effects during and after standardized work tests in normal and anginal subjects. The effects in angina are compared with those obtained in our earlier study with propranolol (Areskog and Adolfsson, 1967).

\section{Materials and Methods}

To determine the equipotent doses of propranolol and I.C.I. 50172 a pilot study was performed in normal subjects. Five men and five women (mean age 39 and 26 years, mean weight 72 and $57 \mathrm{~kg}$., respectively) performed a standardized work test on a bicycle ergometer (Sjöstrand, 1947) before and after the administration of propranolol ( $5 \mathrm{mg}$. intravenously) and I.C.I. 50172 (20 mg. intravenously). The injection rate was 1 and $4 \mathrm{mg}$. per minure, respectively. One test was carried out daily under identical conditions.

Of the group of 19 patients (14 men and 5 women, mean age 56 years, range 38-72 years; mean weight $71 \mathrm{~kg}$., range $50-103 \mathrm{~kg}$. with angina, or coronary insufficiency, or both, showing typical E.C.G. alterations at rest or on a standardized submaximal work test, six had slight to moderate hypertension, and one E.C.G. signs or earlier myocardial infarction. After an interval of some days a further work test was performed 20 minutes after the administration of I.C.I. $50172(20$ mg. intravenously per five-minute run). Six of the patients performed a funther exercise test after at least two weeks' treatment by mouth with I.C.I. $50172(100 \mathrm{mg}$. b.d.). The time, meal-load conditions, and timing of the test were 